\section{Hemodialysis services: are public policies turned to guaranteeing the access?}

\author{
Serviços de hemodiálise: as políticas públicas \\ estão voltadas à garantia do acesso?
}

\author{
Servicios de hemodiálisis: ¿las políticas públicas \\ están dirigidas a garantizar el acceso?
}

\begin{abstract}
The increasing incidence of chronic renal failure in Brazil and the consequential expansion of hemodialysis as a choice for treatment in final stage have to be taken into account to guarantee access to those in need. The ecological study conducted in Mato Grosso do Sul State, Brazil, in 2012, using data from the Brazilian Health Informatics Department (DATASUS) and from the analysis of medical records in 12 clinics, identified and mapped patients on hemodialysis, the distance they travelled and the estimated number of patients. The prevalence of hemodialysis patients in Mato Grosso do Sul State, about 55 per 100,000 inhabitants, is similar to the national average. The analyses indicated concentration of patients in counties with clinics and also geographical gaps that generate displacement of over $100 \mathrm{~km}$ for more than $16 \%$ of patients. The results point to the necessity of strengthening public policies that consider, for decision-making, the decentralization of service, the expansion of home care and the follow-up education for professionals.
\end{abstract}

Renal Dialysis; Health Services Accessibility;

Public Policies
Ana Rita Barbieri 1

Crhistinne Cavalheiro Maymone Gonçalves 2

Maria de Fátima Meinberg Cheade 1

Cristina Souza

Daniel Henrique Tsuha ${ }^{3}$

Kássio Costa Ferreira 1

Lucas Rasi 4

Antonio Conceição Paranhos Filho ${ }^{1}$

\section{Resumo}

A expansão da hemodiálise como escolha para o tratamento da insuficiência renal crônica em seu estágio final precisa ser organizada com garantia de acesso aos que dela necessitam. O estudo ecológico realizado no Mato Grosso do Sul, Brasil, em 2012, mapeou geograficamente pacientes que realizam hemodiálise, as distâncias percorridas, o número estimado de doentes com base em bancos de dados do Departamento de Informática do Sistema Único de Saúde (DATASUS) e análise dos prontuários nas 12 clínicas. A prevalência de pacientes em hemodiálise no estado assemelha-se à média nacional, com aproximadamente 55 pacientes para cada 100 mil habitantes. As análises indicam concentração de pacientes em municípios que possuem as clínicas e vazios geográficos que geram deslocamentos superiores a $100 \mathrm{~km}$ para mais de $16 \%$ dos pacientes. Os resultados sugerem a necessidade de fortalecer políticas públicas que considerem para a tomada de decisão: a desconcentração da oferta de serviços, a ampliação da oferta de procedimentos domiciliares e a educação permanente de profissionais.

Diálise Renal; Acesso aos Serviços de Saúde; Políticas Públicas 


\section{Introduction}

The incidence of chronic renal disease (CKD), reported in populations worldwide, is rising because of the aging population and the associated increase in chronic diseases. Chronic renal failure (CRF) is the final stage of CKD, which leads to the necessity of hemodialysis 1. A study of the Organisation for Economic Co-operation and Development (OECD) indicated an increased prevalence of around 5\% per year in member countries by analyzing data from 1990 to 20092 .

The data shows an increasing prevalence in Brazil. In 2000, 42,000 patients or $431 \mathrm{CRF}$ patients per million (pmp) required dialysis, whereas in 2007, the prevalence of patients on dialysis supported by the Brazilian Unified National Health System (SUS) was 49.8 per 100,000 (or 498 per 1,000,00) inhabitants (http://tabnet. datasus.gov.br/cgi/tabcgi.exe?idb2011/d22.def, accessed on 07/Mar/2014). In 2012, according to the Brazilian Society of Nephrology census, there were 97,586 people on hemodialysis, i.e., approximately 503pmp 3,4,5. From 2002 to 2012, the prevalence doubled, i.e., 97,586 and 48,806 patients, respectively.

In Brazil, since 1988, the state has legally assumed the responsibility to offer healthcare guided by the principles of universality, integrity, and fairness; however, fair access to health services requires joint efforts from the different political and administrative spheres because of the dimensions of the country and large number of towns with less than 20,000 inhabitants, which amount to over $70 \%$ of all Brazilian municipalities 6 .

Furthermore, after the process of strengthening the management of local health systems in the municipalities in the 1990s, healthcare began to be regionalized. Through a Regionalization Director Plan (PDR), the states needed to work together with the municipalities to delineate administrative regions and to establish joint actions and services that could be performed locally. This initiative has allowed the organization of novel healthcare services in these regions, aiming to reduce the inequalities created by distances and poor distribution of health resources.

However, guaranteeing assistance in highcomplexity procedures is an ongoing challenge. Geographical accessibility in a strict sense, i.e., the distance between healthcare services and users, becomes relevant to the analysis of the context because these distances limit the access, reiterating the hypothesis that relationships are more intense when the users are nearer 7,8 .

These characteristics attract the attention of the SUS managers responsible for the cost of hemodialysis 9. In 2000s, there was an increase in dialysis clinics from 550 in 2002 to 651 in 20123. Increase in the number of patients and demand for such clinical intervention was crucial in the formulation of the National Policy of Attention to Renal Patients in 2004 1. CKD increasingly presents an important public health issue, with a strong push toward public policies for health prevention, promotion, and recovery 10,11,12,13. In addition, patients on hemodialysis, with little prospect of no longer requiring treatment, increase the cost of health systems, and their quality of life markedly reduces. Thus, it is becoming increasingly necessary to organize and facilitate patient access to services 13,14,15,16.

The SUS is responsible for financing most services but depends on the private sector for significant assistance by contracts with private and philanthropic institutions. Information released by the Brazilian Ministry of Health revealed that there were over 12 million dialysis sessions in public services in 686 nephrology clinics throughout the country in 201217.

This study investigated the distribution of renal patients with access to hemodialysis treatment in Mato Grosso do Sul State, Brazil, in 2012. We mapped these patients, recorded the distance traveled, and estimated the number of patients according to Brazilian Health Informatics Department (DATASUS. http://www.data sus.gov.br) databases and medical records in 12 clinics. The objective was to discuss patient access to hemodialysis in relation to public policies that are expected to improve equality of access to services.

\section{Methods}

A cross-sectional study was conducted on all SUS patients who underwent hemodialysis in Mato Grosso do Sul State in 2012. Located in the Central Region of Brazil, Mato Grosso do Sul has a low population density $(2,449,024$ people distributed throughout 78 counties) and relies on 12 clinics accredited by SUS for performing hemodialysis procedures distributed among 7 municipalities, and 5 of them are located in Campo Grande, the state capital 18 .

This study considered the division of the state into four sanitary regions, namely Campo Grande, Corumbá, Dourados, and Três Lagoas, which are in turn subdivided into 11 micro-regions defined by the PDR. This plan aims to optimize the resources available in each territory to provide access to diverse health services.

Patient information was obtained from the "s_apadbf" database provided by DATASUS in CD-ROM in compliance with privacy and con- 
fidentiality responsibilities aimed at preserving patient identities. From this database, it was possible to identify patients with the N18.0 code (record in the International Classification of Diseases 10th revision - ICD-10, for chronicle renal failure) who underwent renal replacement therapy (hemodialysis). We could also determine the patient's county of residence and details of their treatment. Patients undergoing peritoneal dialysis were not considered in this study.

For statistical analysis, simple linear regression was used, which allowed the estimation of the number of CKD cases. The coefficient of determination of the model was $60.7 \%\left(\mathrm{R}^{2}\right)$, and the model was statistically significant if $\mathrm{p}<0.001$. Intersections and angular coefficients of the models (lower and upper limits) were calculated for 78 counties.

For information analysis, seven counties where the 12 accredited hemodialysis clinics are located were considered outliers (Aquidauna, Campo Grande, Corumbá, Dourados, Paranaíba, Ponta Porã, and Três Lagoas).

On the basis of the values of lower and upper limits (95\% lower and 95\% upper), the counties were classified into three categories according to the number of patients: (a) underestimated: counties where the number of kidney disease cases was lower than that estimated by the model at its lower limit; (b) normal: counties where the number of kidney disease cases lay between the lower and upper limits estimated by the model; and (c) overestimated: counties where the number of kidney disease cases was higher than that estimated by the model at its upper limit.

The survey used the municipalities of Mato Grosso do Sul as geographic units of analysis. We measured the kilometers traveled by each patient from their town to the clinics. The distance was estimated through Google Maps API (http://www.google.com/MapsAPIs) using highways and paved roads, but the distances were not measured between the points 7,19. The data were tabulated, and the weighted means were extracted.

This study was approved by the Mato Grosso do Sul Federal University Ethics Research Committee (number 141.800, October 25, 2012) with funding from Mato Grosso do Sul State Foundation for the Development of Teaching, Science, and Technology (FUNDECT/PPSUS 2012).

\section{Results}

The Table 1 shows the demographic profile and morbidity of patients on hemodialysis in Mato Grosso do Sul.
Considering the population of Mato Grosso do Sul $(2,449,021$ inhabitants in 2010), the prevalence of people on dialysis at the time was about 59 patients per 100,000 inhabitants, which is more than the DATASUS records that suggested a prevalence of 55.61, very close to the national average (55.47 for the same year) (DATASUS. Indicadores de morbidade. D.22 Prevalência de pacientes em diálise (SUS). http://tabnet.datasus. gov.br/cgi/tabcgi.e.,xe?idb2012/d22.def, accessed on 07/Mar/2014) (Instituto Brasileiro de Geografia e Estatística. Censo populacional 2010: resultados. http://censo2010.ibge.gov.br/, accessed on 13/Jan/2014) 18,20.

Out of the 12 clinics, 5 are based in Campo Grande, the state capital, which accounts for $44.6 \%$ of the patients on hemodialysis. The concentration of patients in the capital is shown in Figure 1. By linear correlation analysis, about 25 percent of counties showed an overestimated currency number of people undergoing hemodialysis, and $15.4 \%$ showed an underestimation, whereas the distribution was normal in $59 \%$ of the municipalities.

These results suggest that the occurrence of cases per county in 2012 was related to the expected number of CKD patients. The analysis showed an overestimation of the number of patients in all the counties providing clinical hemodialysis. Table 2 shows the number of people on hemodialysis for each county and the minimum/ maximum number of estimated CKD patients. The last column classifies the county according to the actual number compared to the estimated number of patients. The bolded lines show the counties that provide clinical hemodialysis.

Figure 2 illustrates the estimated distribution of patients in Mato Grosso do Sul in 11 regions with uneven distribution. It is noteworthy that the clinics are present only in seven sanitary micro-regions, confirming the concentration of services in only a few cities, which does not represent adequate regional distribution of access to treatment.

The ratio of patients on hemodialysis by the site of residence can be seen in Figure 2. It is also possible to see the concentration of patients residing in places where hemodialysis clinics exist. Irrespective of the estimated number of patients, the disparities among counties are enhanced when the coefficients of patients in treatment are analyzed. In addition, it is possible to observe a larger number of counties with fewer patients in treatment.

Disparities can be seen when analyzing the distances traveled by patients living in the counties with hemodialysis services and those from other counties (Table 3 ). 
Table 1

Demographic profile and morbidity of patients on hemodialysis. Mato Grosso do Sul State, Brazil, 2012.

\begin{tabular}{|c|c|c|c|c|c|c|c|c|c|c|}
\hline \multirow[t]{2}{*}{ Variable } & \multicolumn{2}{|c|}{ Campo Grande } & \multicolumn{2}{|c|}{ Corumbá } & \multicolumn{2}{|c|}{ Dourados } & \multicolumn{2}{|c|}{ Três Lagoas } & \multicolumn{2}{|c|}{ Total } \\
\hline & $\mathrm{n}$ & Coefficient & $\mathrm{n}$ & Coefficient & $\mathbf{n}$ & Coefficient & $\mathbf{n}$ & Coefficient & $\mathrm{n}$ & Coefficient \\
\hline \multicolumn{11}{|l|}{ Age group (years) } \\
\hline $0-9$ & 8 & 0.9 & 0 & 0.0 & 3 & 1.0 & 0 & 0.0 & 11 & 0.8 \\
\hline $10-39$ & 181 & 20.9 & 22 & 25.3 & 53 & 17.0 & 40 & 21.9 & 296 & 20.5 \\
\hline $40-59$ & 366 & 42.3 & 32 & 36.8 & 130 & 41.8 & 64 & 35.0 & 592 & 40.9 \\
\hline $60-79$ & 275 & 31.8 & 32 & 36.8 & 117 & 37.6 & 71 & 38.8 & 495 & 34.2 \\
\hline$>80$ & 35 & 4.1 & 1 & 1.2 & 8 & 2.6 & 8 & 4.4 & 52 & 3.6 \\
\hline \multicolumn{11}{|l|}{ Sex } \\
\hline Male & 523 & 60.5 & 46 & 52.9 & 178 & 57.2 & 109 & 59.6 & 856 & 59.2 \\
\hline Female & 342 & 39.5 & 41 & 47.1 & 133 & 42.8 & 74 & 40.4 & 590 & 40.8 \\
\hline \multicolumn{11}{|l|}{ Race (declared) } \\
\hline East Asian & 9 & 1.1 & 0 & 0.0 & 5 & 1.6 & 0 & 0.0 & 14 & 1.1 \\
\hline Caucasian & 392 & 52.5 & 29 & 33.3 & 179 & 57.4 & 70 & 38.5 & 670 & 50.6 \\
\hline Indigenous & 7 & 0.9 & 0 & 0.0 & 9 & 2.9 & 0 & 0.0 & 16 & 1.2 \\
\hline Mixed race & 262 & 35.1 & 50 & 57.5 & 101 & 32.6 & 87 & 47.8 & 500 & 37.7 \\
\hline Black & 76 & 10.2 & 8 & 9.2 & 16 & 5.2 & 25 & 13.7 & 125 & 9.4 \\
\hline \multicolumn{11}{|l|}{ Diagnoses } \\
\hline Diabetes mellitus & 38 & 37.3 & 23 & 22.5 & 41 & 40.2 & 0 & 0.0 & 102 & 7.1 \\
\hline Hypertension & 70 & 36.2 & 5 & 2.6 & 37 & 19.2 & 81 & 42.0 & 193 & 13.3 \\
\hline Nephritic syndromes & 29 & 44.0 & 28 & 42.4 & 9 & 13.6 & 0 & 0.0 & 66 & 4.6 \\
\hline Chronic renal failure & 331 & 57.8 & 26 & 4.5 & 213 & 37.2 & 3 & 0.5 & 573 & 39.6 \\
\hline Polycystic kidney & 4 & 30.8 & 5 & 38.5 & 4 & 30.8 & 0 & 0.0 & 13 & 0.9 \\
\hline Failed kidney transplant & 1 & 50.0 & 0 & 0.0 & 1 & 50.0 & 0 & 0.0 & 2 & 0.1 \\
\hline Not recorded & 392 & 78.9 & 0 & 0.0 & 6 & 1.2 & 99 & 19.9 & 497 & 34.4 \\
\hline
\end{tabular}

Figure 1

Distribution of hemodialysis patients in the counties. Mato Grosso do Sul State, Brazil, 2012.

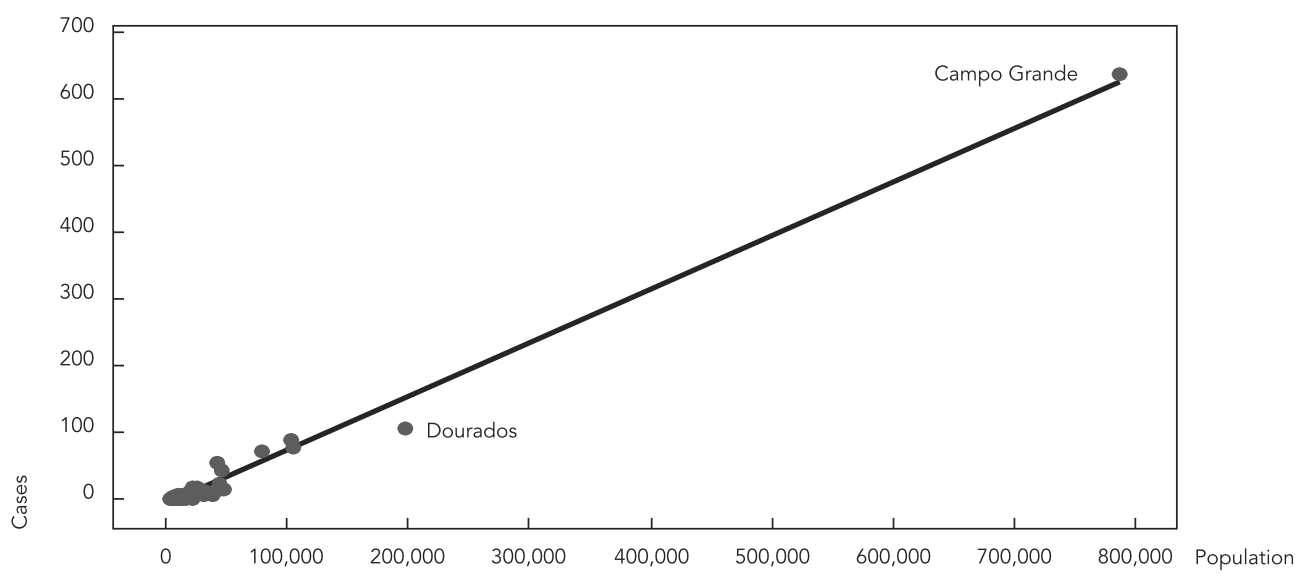


Table 2

Number of patients in hemodialysis per county in Mato Grosso do Sul State, Brazil; number of patients in hemodialysis with outlier counties are in bold; and the estimated number of chronic renal failure (CRF) patients according to the classification.

\begin{tabular}{|c|c|c|c|c|c|c|}
\hline County & Cases & Population & Hemodialysis & $\begin{array}{l}\text { Minimum } \\
\text { estimated }\end{array}$ & $\begin{array}{l}\text { Maximum } \\
\text { estimated }\end{array}$ & Classification \\
\hline Água Clara & 6 & 14,424 & No & 2.33 & 7.24 & Normal \\
\hline Alcinópolis & 1 & 4,569 & No & -0.75 & 2.69 & Normal \\
\hline Amambai & 8 & 34,730 & No & 8.67 & 16.63 & Underestimated \\
\hline Anastácio & 18 & 23,835 & No & 5.27 & 11.59 & Overestimated \\
\hline Anaurilândia & 1 & 8,493 & No & 0.47 & 4.50 & Normal \\
\hline Angélica & 3 & 9,185 & No & 0.69 & 4.82 & Normal \\
\hline Antônio João & 1 & 8,208 & No & 0.39 & 4.37 & Normal \\
\hline Aparecida do Taboado & 9 & 22,320 & No & 4.79 & 10.89 & Normal \\
\hline Aquidauana & 43 & 45,614 & Yes & 12.07 & 21.66 & Overestimated \\
\hline Aral Moreira & 4 & 10,251 & No & 1.02 & 5.31 & Normal \\
\hline Bandeirantes & 1 & 6,609 & No & -0.11 & 3.63 & Normal \\
\hline Bataguassu & 1 & 19,839 & No & 4.02 & 9.75 & Underestimated \\
\hline Batayporã & 1 & 10,936 & No & 1.24 & 5.63 & Underestimated \\
\hline Bela Vista & 8 & 23,181 & No & 5.06 & 11.29 & Normal \\
\hline Bodoquena & 5 & 7,985 & No & 0.32 & 4.27 & Overestimated \\
\hline Bonito & 4 & 19,587 & No & 3.94 & 9.63 & Normal \\
\hline Brasilândia & 1 & 11,826 & No & 1.52 & 6.04 & Underestimated \\
\hline Caarapó & 15 & 25,767 & No & 5.87 & 12.49 & Overestimated \\
\hline Camapuã & 7 & 13,625 & No & 2.08 & 6.87 & Overestimated \\
\hline Campo Grande & 638 & 786,797 & Yes & 243.63 & 364.22 & Overestimated \\
\hline Caracol & 0 & 5,398 & No & -0.49 & 3.07 & Normal \\
\hline Cassilândia & 17 & 20,966 & No & 4.37 & 10.27 & Overestimated \\
\hline Chapadão do Sul & 7 & 19,648 & No & 3.96 & 9.66 & Normal \\
\hline Corguinho & 1 & 4,862 & No & -0.66 & 2.82 & Normal \\
\hline Coronel Sapucaia & 7 & 14,064 & No & 2.21 & 7.08 & Normal \\
\hline Corumbá & 76 & 103,703 & Yes & 30.22 & 48.51 & Overestimated \\
\hline Costa Rica & 5 & 19,695 & No & 3.97 & 9.68 & Normal \\
\hline Coxim & 11 & 32,159 & No & 7.87 & 15.44 & Normal \\
\hline Deodápolis & 4 & 12,139 & No & 1.61 & 6.19 & Normal \\
\hline Dois Irmãos do Buriti & 6 & 10,363 & No & 1.06 & 5.37 & Overestimated \\
\hline Douradina & 4 & 5,364 & No & -0.50 & 3.06 & Overestimated \\
\hline Dourados & 107 & 196,035 & Yes & 59.07 & 91.18 & Overestimated \\
\hline Eldorado & 5 & 11,694 & No & 1.47 & 5.98 & Normal \\
\hline Fátima do Sul & 6 & 19,035 & No & 3.77 & 9.37 & Normal \\
\hline Figueirão & 0 & 2,928 & No & -1.26 & 1.93 & Normal \\
\hline Glória de Dourados & 1 & 9,927 & No & 0.92 & 5.17 & Normal \\
\hline Guia Lopes da Laguna & 6 & 10,366 & No & 1.06 & 5.37 & Overestimated \\
\hline
\end{tabular}

(continues) 
Table 2 (continued)

\begin{tabular}{|c|c|c|c|c|c|c|}
\hline County & Cases & Population & Hemodialysis & $\begin{array}{l}\text { Minimum } \\
\text { estimated }\end{array}$ & $\begin{array}{l}\text { Maximum } \\
\text { estimated }\end{array}$ & Classification \\
\hline Iguatemi & 1 & 14,875 & No & 2.47 & 7.45 & Underestimated \\
\hline Inocência & 3 & 7,669 & No & 0.22 & 4.12 & Normal \\
\hline Itaporã & 7 & 20,865 & No & 4.34 & 10.22 & Normal \\
\hline Itaquiraí & 4 & 18,614 & No & 3.64 & 9.18 & Normal \\
\hline Ivinhema & 12 & 22,341 & No & 4.80 & 10.90 & Overestimated \\
\hline Japorã & 0 & 7,731 & No & 0.24 & 4.15 & Underestimated \\
\hline Jaraguari & 2 & 6,341 & No & -0.20 & 3.51 & Normal \\
\hline Jardim & 11 & 24,346 & No & 5.43 & 11.83 & Normal \\
\hline Jateí & 1 & 4,011 & No & -0.93 & 2.43 & Normal \\
\hline Juti & 1 & 5,900 & No & -0.34 & 3.30 & Normal \\
\hline Ladário & 11 & 19,617 & No & 3.95 & 9.64 & Overestimated \\
\hline Laguna Carapã & 1 & 6,491 & No & -0.15 & 3.58 & Normal \\
\hline Maracaju & 7 & 37,405 & No & 9.51 & 17.86 & Underestimated \\
\hline Miranda & 15 & 25,595 & No & 5.82 & 12.41 & Overestimated \\
\hline Mundo Novo & 3 & 17,043 & No & 3.15 & 8.45 & Underestimated \\
\hline Naviraí & 15 & 46,424 & No & 12.32 & 22.03 & Normal \\
\hline Nioaque & 2 & 14,391 & No & 2.32 & 7.23 & Underestimated \\
\hline Nova Alvorada do Sul & 8 & 16,432 & No & 2.95 & 8.17 & Normal \\
\hline Nova Andradina & 14 & 45,585 & No & 12.06 & 21.65 & Normal \\
\hline Novo Horizonte do Sul & 1 & 4,940 & No & -0.64 & 2.86 & Normal \\
\hline Paranaíba & 54 & 40,192 & Yes & 10.38 & 19.15 & Overestimated \\
\hline Paranhos & 2 & 12,350 & No & 1.68 & 6.28 & Normal \\
\hline Pedro Gomes & 2 & 7,967 & No & 0.31 & 4.26 & Normal \\
\hline Ponta Porã & 72 & 77,872 & Yes & 22.15 & 36.57 & Overestimated \\
\hline Porto Murtinho & 3 & 15,372 & No & 2.62 & 7.68 & Normal \\
\hline Ribas do Rio Pardo & 5 & 20,946 & No & 4.36 & 10.26 & Normal \\
\hline Rio Brilhante & 5 & 30,663 & No & 7.40 & 14.75 & Underestimated \\
\hline Rio Negro & 1 & 5,036 & No & -0.61 & 2.90 & Normal \\
\hline Rio Verde de Mato Grosso & 8 & 18,890 & No & 3.72 & 9.31 & Normal \\
\hline Rochedo & 3 & 4,928 & No & -0.64 & 2.85 & Overestimated \\
\hline Santa Rita do Pardo & 3 & 7,259 & No & 0.09 & 3.93 & Normal \\
\hline São Gabriel do Oeste & 7 & 22,203 & No & 4.76 & 10.84 & Normal \\
\hline Selvíria & 1 & 6,287 & No & -0.21 & 3.48 & Normal \\
\hline Sete Quedas & 1 & 10,780 & No & 1.19 & 5.56 & Underestimated \\
\hline Sidrolândia & 24 & 42,132 & No & 10.98 & 20.05 & Overestimated \\
\hline Sonora & 3 & 14,833 & No & 2.45 & 7.43 & Normal \\
\hline Tacuru & 3 & 10,215 & No & 1.01 & 5.30 & Normal \\
\hline Taquarussu & 0 & 3,518 & No & -1.08 & 2.20 & Normal \\
\hline Terenos & 3 & 17,146 & No & 3.18 & 8.50 & Underestimated \\
\hline Três Lagoas & 88 & 101,791 & Yes & 29.62 & 47.62 & Overestimated \\
\hline Vicentina & 1 & 5,901 & No & -0.34 & 3.30 & Normal \\
\hline
\end{tabular}


Figure 2

Distribution of hemodialysis clinics in the counties according to the estimated number of patients, and the ratio of hemodialysis patients. Mato Grosso do Sul State, Brazil, 2012.

2a) Estimate of patients according to the classification: underestimated, normal and overestimated.

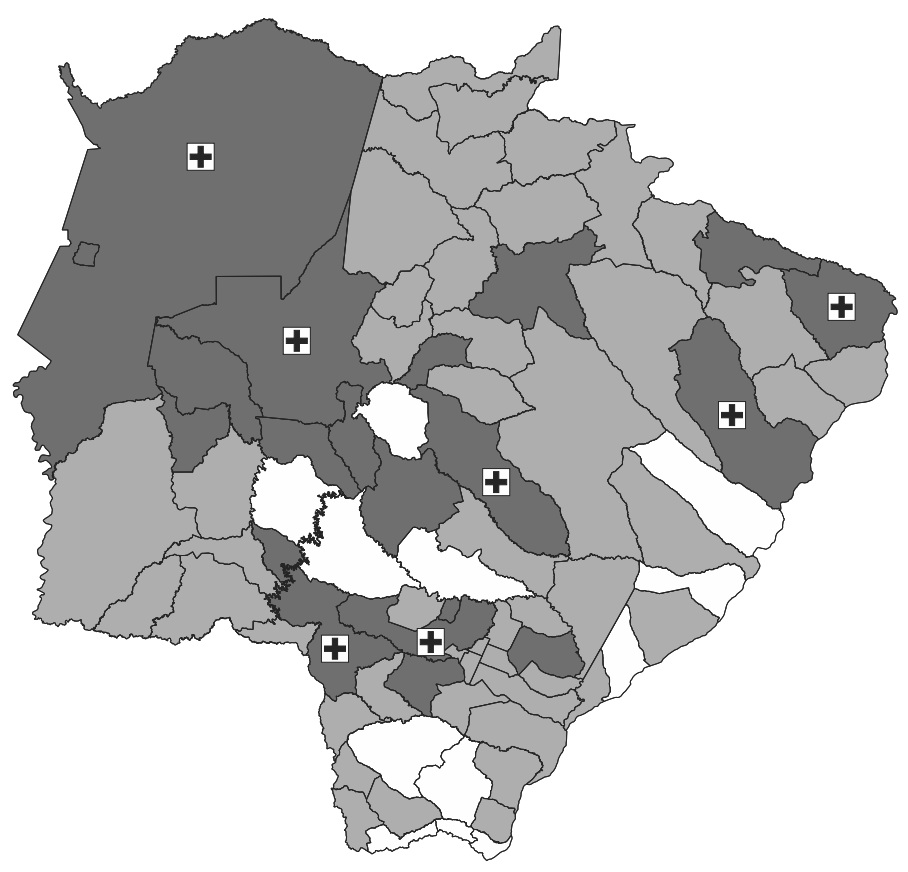

2b) Distribution of hemodialysis patients.

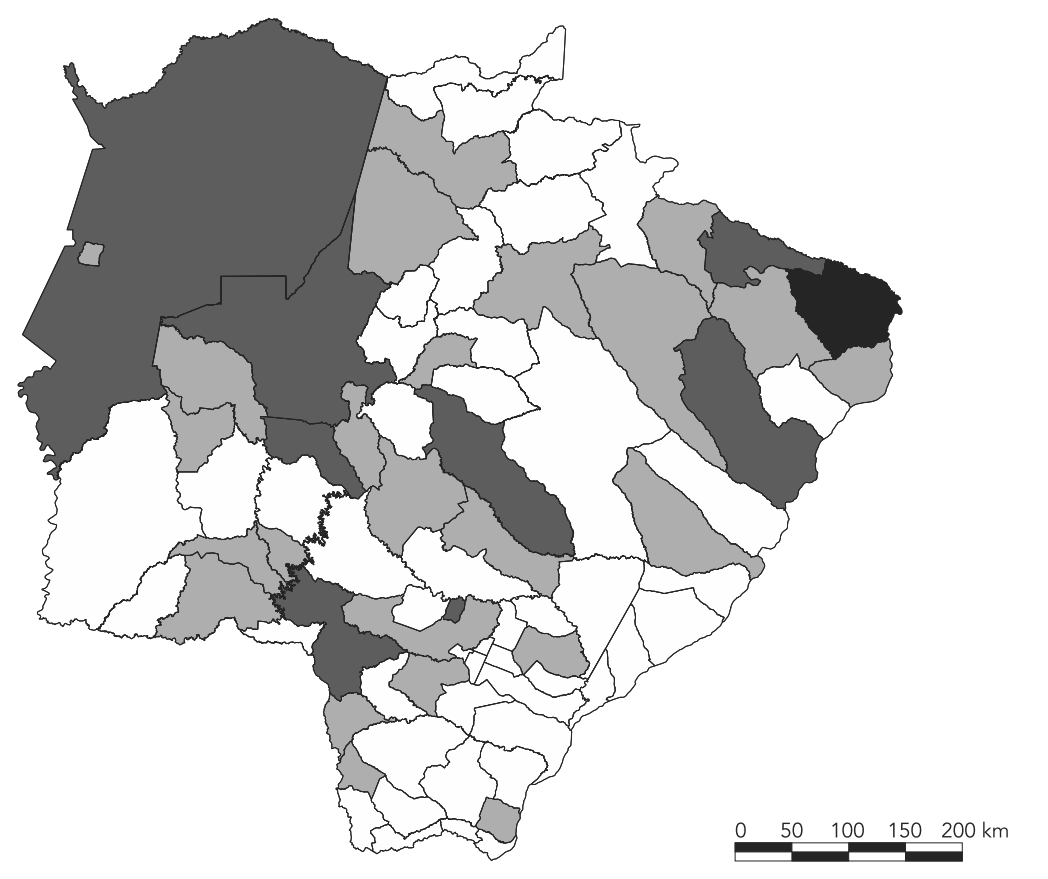

\section{Classification}

$\square$ Understimated

Normal

Overestimated

Hemodialysis clinics
Patients per

10,000 inhabitants

0.000-3.3588

3.3589-6.7177

$6.7178-10.0766$

$10.0767-13.4355$

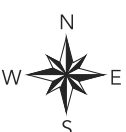




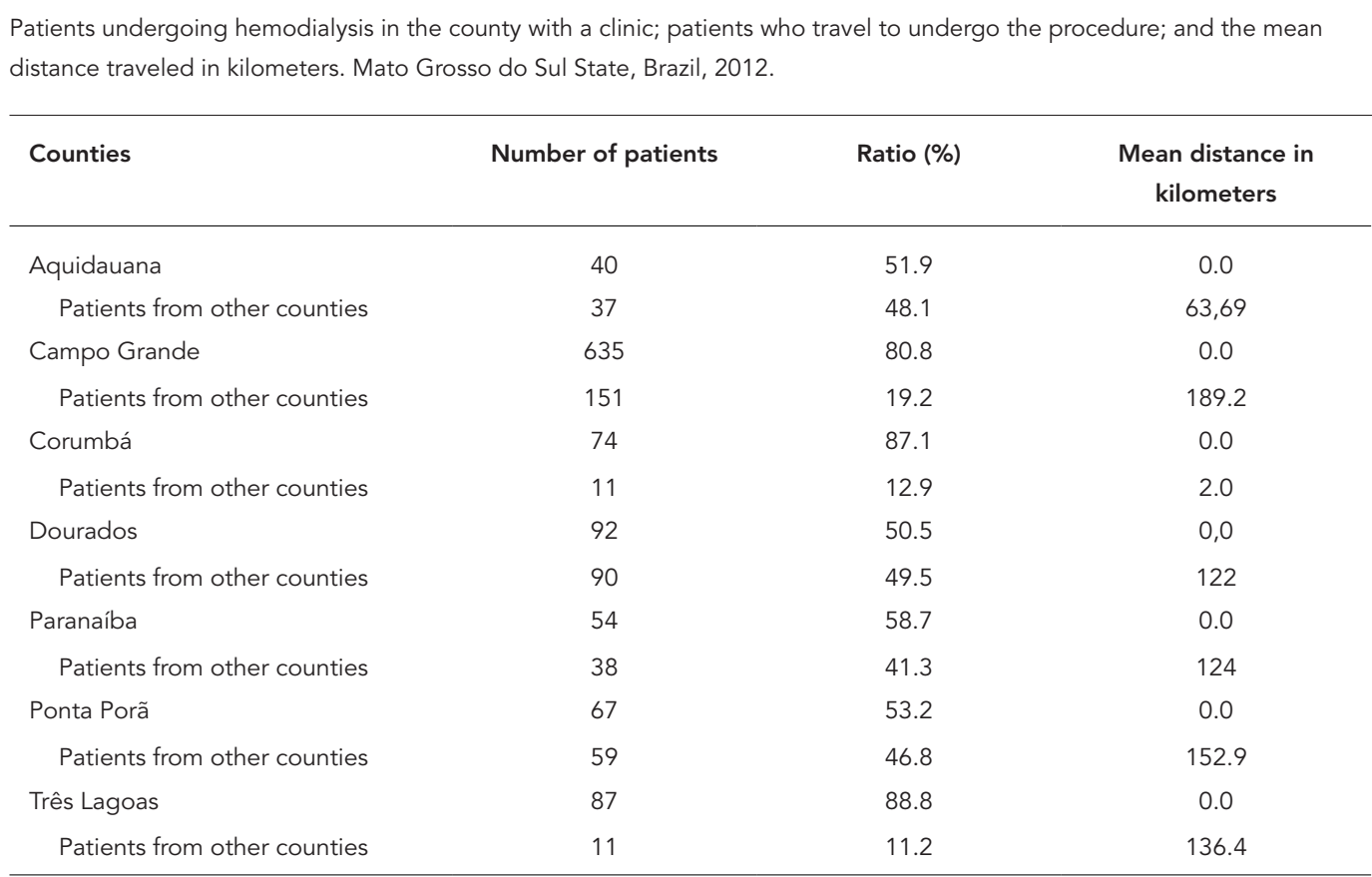

Among patients, $72.4 \%$ reported their county of residence as being the same as the location of their clinic, whereas $16.9 \%$ travel distances of longer than $100 \mathrm{~km}$. On observing the proportion of patients residing in the counties that offer the service, the clinics in Aquidauna, Dourados, and Ponta Porã have a balanced distribution of patients living in the city and those who travel from another county for treatment. The lowest average distance $(63.69 \mathrm{~km})$ was observed in Aquidauna, whereas Campo Grande recorded an average distance of three times higher $(189.2 \mathrm{~km})$.

\section{Discussion}

Hemodialysis is required when the kidneys are temporarily unable to eliminate toxic substances from the blood. The increased prevalence of CKD leading to permanent CRF can be seen worldwide 2 .

Considering the determinants of CRF, the disease should have a more or less homogeneous geographic distribution, which was not found in this study. Our findings indicate a displacement of patients towards the treatment centers. The difficult balance between supply and demand has probably generated a concentration of patients residing in counties with clinical hemodialysis services in Mato Grosso do Sul, which implies that patients possibly had to relocate to receive treatment.

The concentration of services should be considered in conjunction with the concept of decentralization, a health policy aimed at increasing equal access to treatment at the local level with more complex services available at the central level 21,22. The concentration/dispersion duality, from the viewpoint of supply of services, has implications for social justice and greater synergy between different points of attention 22,23.

The complex balance between access and concentration of services needs to be considered in the formulation of health policies. On the one hand, if complex services are geographically concentrated in different intensities, the synergy between the different types of treatment is an extremely important element in the organization of the system. It needs to consider the flow of treatment, communication, and mutual cooperation to strengthen the capacity of the response 21,23 .

Large number of services in regions with high population density is a recurring issue in Brazil and elsewhere in the world, and access to hemodialysis therapy is no exception to this rule 3,9 . This problem is not new. In 1998, a Brazilian National Bank for Economic and Social Development (BNDES) report showed a concentration of hemodialysis patients and clinics in the southern and southeastern regions, which continues to this day 24 . A study conducted in Portugal highlighted 
a higher concentration of hemodialysis clinics in the coastal regions. The average distance traveled by patients was about $33 \mathrm{~km}$, ranging from $20 \mathrm{~km}$ in Lisbon to $75 \mathrm{~km}$ for patients living in the Vale do Tejo region 21. These numbers differ from the displacement of Mato Grosso do Sul where patients travel longer distances.

The geographical dimension of access is one aspect to be debated in the formulation/implementation of public policies that, in this study, are being outlined by the offer of either the clinics or the specialists in the disease. To ensure equality in health in a country with broad territorial dimensions, studies and research should be focused on these issues to support processes of better governmental decision-making because public policies aimed at promoting guaranteed access must be devised taking into account multiple variables that form the complex health status of individuals and communities.

On the other hand, the most complex procedures must be arranged to allow for scale not only for economic reasons, in which volume contributes to cost reduction, but also for the quality of services. In high-complexity procedures, large volume permits the specialization of resources, which leads to a higher quality 25,26 . Although this study has not examined the production of equipment or clinics, it is known that the distribution of services throughout the regions must take into account the human aspects involved in treatment 27 . The supply and distribution of hemodialysis equipment where the procedure is offered continuously, with the peculiarity of the patient undergoing it two to three times in a week, can either facilitate or restrict access 28 .

For patients undergoing weekly hemodialysis, distance is a significant barrier to access. The study identified patients traveling long distances for this procedure, and this limitation needs to be addressed when organizing services for this group in particular. The concentration of clinics in the capital, as shown in Figure 1, and in 6 other cities in a state as large as Mato Grosso do Sul, may result in migrations in order to reduce barriers to treatment or, in the worst case scenario, result in premature deaths, as a result of the lack of treatment. This situation should be considered when designing public health policies, with a view of distributing therapeutic resources differently from providing specialized care, where concentration of health services and volume of care are the most important criteria 8 .

Public policies in this area should be sufficiently efficient to offer hemodialysis based on the logic of the economy of scale, but they must take into account the geographical dimension of the territory as a major factor in guaranteed access, especially in Mato Grosso do Sul, which has a low population density in a large territorial space. As indicated in this study, the concentration of dialysis clinics in few cities (only 7 out of the 11 sanitary micro-regions) and the long geographical distances can limit patient access to treatment. This hypothesis is supported by the inhomogeneous distribution of chronic renal patients in the state, with a strong concentration in the counties that host the clinics, as seen in Figure 1.

The distribution of services is a complex issue and poses a challenge to managers who need to reconcile public and outsourced services to meet the demand. Although it is not feasible to offer hemodialysis treatment in all the counties, it is necessary to establish a better regional distribution, considering the 11 sanitary micro regions defined by the PDR, which would contribute to the reduction of travel distances for geographically distributed groups.

The referencing protocols with defined responsibilities and integrated information systems would reduce patient displacement and offer safer and easier access to treatment. Thus, decisions regarding access to treatment should incorporate social and political viewpoints to achieve adequate coverage 29,30 .

Because the concern about greater focus on economic considerations prevails, the inequality of access is a relevant issue for most European countries, many of which have already developed plans to cope with this challenge. To reduce these inequalities, the use of efficient and integrated information systems is recommended to ensure both initial access to treatment and continuity of care 33,32,33,34.

In Brazil, in 2010, $9.4 \%$ of patients on dialysis underwent peritoneal dialysis ${ }^{3}$. In some European countries, up to $40 \%$ of patients receive this type of dialysis, with access to this modality increasing. Portugal is also expanding the service; in the United States and Canada, there are studies that have assessed the differences in costs and quality of life resulting from these different modalities of dialysis 31,35 .

Peritoneal dialysis performed in home results in cost savings and improves the quality of life of patients as frequent travel is not necessary 27,28 . Expanding the range of options for treatment, peritoneal dialysis has received investments from the Brazilian Ministry of Health, which launched the program Melhor em Casa with the objective of expanding the service 36 .

Homecare procedures should be recommended in compliance with the established protocols but they still involve difficulties. Doctors may not offer patients the procedure due to 
this. In relation to patients, the level of schooling, understanding their health condition, family involvement, and the physical and hygienic conditions in the household need to be considered before deciding the appropriate treatment 31,32,35 .

\section{Conclusions}

The present study used secondary data sources such as DATASUS and patient charts. The analyzed aspects related exclusively to the available data, which restricted the assessment of the socio-demographic profile and patient morbidity. The available data allowed the analysis of the distance traveled, in kilometers. Despite these limitations, this study indicates that the barrier of distance must be addressed when proposing policies in the health sector, which can incorporate different strategies and solutions, considering that distance is a relevant factor for the equality of access of kidney patients to dialysis services.

The results of this study indicate that when planning health service policies, three important aspects should be considered: (a) human aspects along with the issues surrounding the economy of scale and service decentralization; (b) encouragement of alternative treatments to hemodialysis, such as peritoneal dialysis, especially at home; and (c) the structure of efficient and inte- grated information systems to provide patients with both initial access and continuing healthcare, discouraging a requirement for a change of address/county just to access treatment.

By identifying patients undergoing hemodialysis in Mato Grosso do Sul and mapping the county of residence and the place of treatment, it was possible to identify problems in access to treatment. The results of this survey pointed out inequalities in patient access to an increasingly necessary treatment.

Even with policies formulated to promote the equality of access, the PDR for instance, it appears that this barrier has not been overcome. The managers are responsible for facing the issues concerning patient access to treatment, considering the territory and its extension, the health of the population, and the existing public and private services.

To provide adequate services for chronic renal patients, it is necessary to devise strategies that combine the offer of different treatment options with investments in professional training; the implementation of integrated and efficient regulatory mechanisms are also important. This would improve communication between the different treatment centers and enable the decentralization of services, reducing geographical distances between patient and treatment.

\section{Resumen}

Este trabajo trata sobre la expansión de la hemodiálisis, como una opción para el tratamiento de la insuficiencia renal crónica en su fase final, así como la necesidad de organizarse para garantizar el acceso a las personas necesitadas. Se realizó un estudio ecológico en Mato Grosso do Sul, Brasil, en 2012 con pacientes asignados geográficamente, en tratamiento de hemodiálisis; analizando distancias, número estimado de pacientes, a partir de bases de datos del Departamiento de Informática del Sistema Único de Salud (DATASUS), y análisis de los registros de pacientes en 12 clínicas. La prevalencia de pacientes en hemodiálisis en el estado se asemeja a la media nacional, con aproximadamente 55 pacientes por cada 100.000 habitantes. El análisis indi ca la concentración de los pacientes en los municipios que tienen deficiencias clínicas y geográficas, que generan desplazamientos a más de $100 \mathrm{~km}$ a un $16 \%$ de los pacientes. Los resultados sugieren la necesidad de fortalecer las políticas públicas, con el fin de que tengan en cuenta para la toma de decisiones, la descentralización de la prestación de servicios, la ampliación de la oferta de los procedimientos de la vivienda y la educación continua de los profesionales.

Diálisis Renal; Accesibilidad a los Servicios de Salud; Políticas Públicas 


\section{Contributors}

A. R. Barbieri and C. C. M. Gonçalves contributed on drafting the article; analysis and interpretation of data; writing of the paper; revision of article for important intellectual content. M. F. M. Cheade collaborated on drafting the article; analysis and interpretation of data;revision of article for important intellectual content. C. Souza, D. H. Tsuha and K. C. Ferreira contributed with acquisition of data; analysis and interpretation of data; writing of the paper; revision of article. L. Rasi and A. C. Paranhos Filho participated on with drafting the article; analysis and interpretation of data; writing of the paper.

\section{References}

1. Peixoto ERM, Reis IA, Machado EL, Andrade EIG, Acurcio FA, Cherchiglia ML. Diálise planejada e a utilização regular da atenção primária à saúde entre os pacientes diabéticos do Município de Belo Horizonte, Minas Gerais, Brasil. Cad Saúde Pública 2013; 29:1241-50.

2. Organisation for Economic Co-operation and Development. Treatment of renal failure (dialysis and kidney transplants). In: Organisation for Economic Co-operation and Development, editor. Health at a Glance 2011. Paris: Organisation for Economic Co-operation and Development; 2011. p. 92-5. (OECD Indicators).

3. Sociedade Brasileira de Nefrologia. Censo de diálise: SBN 2012. http://www.sbn.org.br/pdf/publi co2012.pdf (accessed on 15/Dec/2013).

4. Bastos MG, Kirsztajn GM. Chronic kidney disease: importance of early diagnosis, immediate referral and structured interdisciplinary approach to improve outcomes in patients not yet on dialysis. J Bras Nefrol 2011; 33:93-108.

5. Sesso RC, Lopes AA, Thomé FS, Lugon JK, Watanabe Y, Santos DR. Relatório do Censo Brasileiro de Diálise Crônica 2012. J Bras Nefrol 2014; 36:48-53.

\section{Acknowledgments}

The authors would like to thank the State Health Department of Mato Grosso do Sul, especially Emiliana Kohatsu, for guidance on the information systems; DATASUS, for information and explanations; the hemodialysis clinics taking part in the study; and FUNDECT, for financing the research.
6. Instituto Brasileiro de Geografia e Estatística. Indicadores sociais municipais - 2000. Tabela 1 - Número de municípios, população residente, por situação do domicílio, taxa de crescimento e razão de dependência, segundo as Unidades da Federação e classes de tamanho da população dos municípios - Brasil - 2000. http://www.ibge.gov.br/home/esta tistica/populacao/indicadores_sociais_municipais/ tabelale.shtm (accessed on 09/Nov/2014).

7. Gu W, Wang X, McGregor ES. Optimization of preventive health care facility locations. Int J Health Geogr 2010; 9:17.

8. Oliveira EXG, Travassos C, Carvalho MS. Acesso à internação hospitalar nos municípios brasileiros em 2000: territórios do Sistema Único de Saúde. Cad Saúde Pública 2004; 20 Suppl 2:S298-309.

9. Bersan SAL, Amaral CFS, Gomes IC, Cherchiglia ML. Letalidade e internações de pacientes em hemodiálise em plano de saúde. Rev Saúde Pública 2013; 47:624-33.

10. Medina-Pestana JO, Galante NZ, Tedesco-Silva Jr H, Harada KM, Garcia VD, Abbud-Filho M, et al. O contexto do transplante renal no Brasil e a sua disparidade geográfica. J Bras Nefrol 2011; 33:472-84. 
11. Kaitelidou D, Ziroyanis PN, Maniadakis N, Liaropoulos L, Theodoro M. The socioeconomic impact of hemodialysis. Hippokratia 2004; 8:81-7.

12. Manns BJ, Mendelssohn DC, Taub KJ. The economics of end-stage renal disease care in Canada: incentives and impact on delivery of care. Int J Health Care Finance Econ 2007; 7:149-69.

13. Sancho LG, Dain S. Análise de custo-efetividade em relação às terapias renais substitutivas: como pensar estudos em relação a essas intervenções no Brasil? Cad Saúde Pública 2008; 24:1279-90.

14. Cruz MC, Andrade C, Urruta M, Draibe S, Nogueira-Martins LA, Sesso RCC. Quality of life in patients with chronic kidney disease. Clinics (São Paulo) 2011; 66:991-5.

15. Spiegel BM, Melmed G, Robbins S, Esrailian E. Biomarkers and health-related quality of life in endstage renal disease: a systematic review. Clin J Am Soc Nephrol 2008; 3:1759-68.

16. Poppe C, Geert C, Hanoulle I, Vogelaers D, Petrovic D. Improving quality of life in patients with chronic kidney disease influence of acceptance and personality. Nephrol Dial Transplant 2013; 28:116-21.

17. Portal Brasil. Rede pública de saúde recebe mais recursos para serviços de nefrologia. http://www. brasil.gov.br/saude/2013/03/rede-publica-de-sau de-recebe-mais-recursos-para-servicos-de-nefrolo gia (accessed on 07/Mar/2014).

18. Departamento de Descentralização da Gestão da Assistência, Secretaria de Assistência à Saúde, Ministério da Saúde. Regionalização da assistência à saúde: aprofundando a descentralização com equidade no acesso. Norma Operacional da Assistência à Saúde: NOAS-SUS 01/02 (Portaria MS/GM no 373, de 27 de fevereiro de 2002 e regulamentação complementar). Brasília: Ministério da Saúde; 2002. (Série A Normas e Manuais Técnicos).

19. Ministério da Saúde. Introdução à estatística espacial para saúde pública. Brasília: Ministério da Saúde; 2007. (Série B. Textos Básicos em Saúde).

20. Barbieri AR, Gonçalves CCM, Souza C, Fukuda RY, Ferreira KC, Cheade MFM. Análise do acesso dos pacientes à hemodiálise em Mato Grosso do Sul, Brasil. In: I Congresso de Geografia da Saúde dos Países de Língua Portuguesa. A geografia da saúde no cruzamento de saberes. Coimbra: Edições Humus; 2014. p. 132-6.

21. Centro de Estudos de Gestão e Economia Aplicada, Faculdade de Economia e Gestão, Universidade Católica Portuguesa. Estrutura de mercado e performance nos serviços de hemodiálise em Portugal. Relatório final. https://www.ers.pt/uploads/ writer_file/document/99/825007_rel.pdf (accessed on $21 / \mathrm{Jan} / 2014$ ).

22. Hortale V, Pedroza M, Rosa MLG. Operacionalizando as categorias acesso e descentralização na análise de sistemas de saúde. Cad Saúde Pública 2000; 16:231-9.

23. Gonçalo S. Cuidados de saúde e território: um debate em torno de uma abordagem integrada. Saúde Soc 2013; 22:815-29.
24. Souza Melo PR, Rios ECSD, Gutierrez RMV. Equipamentos para hemodiálise. BNDES Setorial 2000; (12):105-34.

25. Gaynor M, Seider H, Vogt WB. The volume-outcome effect, scale economies, and learning-bydoing. Health Serv Res 2009; 44:1960-82.

26. Antti Peltokorpi A, Torkki P, Jousela I, Lepäntalo M. Economy of scale and scope in healthcare operations: lessons from surgical services. In: POMS 23rd Annual Conference. http://www.pomsmeet ings.org/ConfProceedings/025/FullPapers/FullPa per_files/025-0989.pdf (accessed on 19/Feb/2014).

27. Dahlgren G, Whitehead M. Concepts and principles for tackling social inequities in health: levelling up part I and part II. Copenhagen: WHO Regional Office for Europe; 2006.

28. Judge K, Platt S, Costongs C, Jurczak K. Health inequalities: a challenge for Europe. UK Presidency of the EU; 2005. http://ec.europa.eu/health/ph_deter minants/socio_economics/documents/ev_060302_ rd05_en.pdf (accessed on 19/Mar/2014).

29. Furtado C, Pereira J. Equidade e acesso aos cuidados de saúde. Lisboa: Escola Nacional de Saúde Pública, Universidade Nova de Lisboa; 2010.

30. Travassos C, Castro MSM. Determinantes e desigualdades sociais no acesso e utilização dos serviços. In: Giovanella L, Escorel S, Lobato LVC, Noronha, JC, Carvalho AI, organizadores. Política e sistema de saúde no Brasil. Rio de Janeiro: Editora Fiocruz; 2008. p. 215-43.

31. Young BA, Chan C, Blagg C, Lockridge R, Golper T, Finkelstein F, et al. How to overcome barriers and establish a successful home HD Program. Clin J Am Soc Nephrol 2012; 7:2023-32.

32. Nesrallah GE, Lindsay RM, Cuerden MS, Garg AX, Port F, Austin PC, et al. Intensive hemodialysis associates with improved survival compared with conventional hemodialysis. J Am Soc Nephrol 2012; 23:696-705.

33. Ministry of Social Affairs and Health. National action plan to reduce health inequalities 2008-2011. Helsinki: Ministry of Social Affairs and Health; 2008.

34. Swedish National Institute of Public Health. Tackling health inequalities in Sweden: an overview. http://ec.europa.eu/health/social_determinants / docs/sweden_rd01_en.pdf (accessed on 24/Mar/ 2014).

35. Muehrer RJ, Schatell D, Witten B, Gangnon R, Becker BN, Hofmann RM. Factors affecting employment at initiation of dialysis. Clin J Am Soc Nephrol 2011; 6:489-96.

36. Ministério da Saúde. Portaria no 963, de 27 de maio de 2013. Redefine a atenção domiciliar no âmbito do Sistema Único de Saúde (SUS). Diario Oficial da União 2013; 28 mai.

Submitted on 10/May/2014

Final version resubmitted on 23/Nov/2014

Approved on 05/Feb/2015 